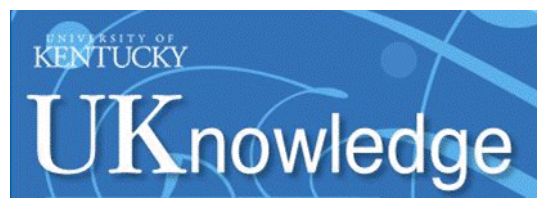

University of Kentucky

UKnowledge

\title{
Lithologic Controls on Focused Erosion and Intraplate Earthquakes in the Eastern Tennessee Seismic Zone
}

\author{
Sean F. Gallen \\ Colorado State University \\ J. Ryan Thigpen \\ University of Kentucky, ryan.thigpen@uky.edu
}

Follow this and additional works at: https://uknowledge.uky.edu/ees_facpub

Part of the Geophysics and Seismology Commons

Right click to open a feedback form in a new tab to let us know how this document benefits you.

\section{Repository Citation}

Gallen, Sean F. and Thigpen, J. Ryan, "Lithologic Controls on Focused Erosion and Intraplate Earthquakes in the Eastern Tennessee Seismic Zone" (2018). Earth and Environmental Sciences Faculty Publications. 13.

https://uknowledge.uky.edu/ees_facpub/13

This Article is brought to you for free and open access by the Earth and Environmental Sciences at UKnowledge. It has been accepted for inclusion in Earth and Environmental Sciences Faculty Publications by an authorized administrator of UKnowledge. For more information, please contact UKnowledge@lsv.uky.edu. 


\section{Lithologic Controls on Focused Erosion and Intraplate Earthquakes in the Eastern Tennessee Seismic Zone}

\section{Digital Object Identifier (DOI)}

https://doi.org/10.1029/2018GL079157

Notes/Citation Information

Published in Geophysical Research Letters, v. 45, issue 18, p. 9569-9578.

@2018. American Geophysical Union. All Rights Reserved.

The copyright holder has granted the permission for posting the article here 


\section{Geophysical Research Letters}

\section{RESEARCH LETTER}

10.1029/2018GL079157

Key Points:

- Approximately $\sim 3,500 \mathrm{~km}^{3}$ of rock has been eroded from an $\sim 70$ by 350-km corridor of erodible rock units in the Upper Tennessee River basin

- The zone of preferential erosion lies directly above the intraplate eastern Tennessee seismic zone

- Modeling indicates focused erosion perturbed local crustal stress allowing pre existing structures to slip in the regional stress field

Supporting Information:

- Supporting Information S1

- Movie S1

Correspondence to:

S. F. Gallen,

sean.gallen@colostate.edu

\section{Citation:}

Gallen, S. F., \& Thigpen, J. R. (2018). Lithologic controls on focused erosion and intraplate earthquakes in the eastern Tennessee seismic zone. Geophysical Research Letters, 45, 9569-9578. https://doi.org/10.1029/ 2018GL079157

Received 8 JUN 2018 Accepted 6 SEP 2018 Accepted article online 11 SEP 2018 Published online 27 SEP 2018

\section{Lithologic Controls on Focused Erosion and Intraplate Earthquakes in the Eastern Tennessee Seismic Zone}

\author{
Sean F. Gallen ${ }^{1,2}$ (D) and J. Ryan Thigpen ${ }^{3}$ \\ ${ }^{1}$ Department of Geosciences, Colorado State University, Fort Collins, CO, USA, ${ }^{2}$ Department of Earth Sciences, Geological \\ Institute, ETH Zürich, Zürich, Switzerland, ${ }^{3}$ Department of Earth and Environmental Sciences, University of Kentucky, \\ Lexington, KY, USA
}

Abstract We present a new geomorphic model for the intraplate eastern Tennessee seismic zone (ETSZ). Previous studies document that the Upper Tennessee drainage basin is in a transient state of adjustment to $\sim 150 \mathrm{~m}$ of base level fall that occurred in the Late Miocene. Using quantitative geomorphology, we demonstrate that base level fall resulted in the erosion of $\sim 3,500 \mathrm{~km}^{3}$ of highly erodibility rock in an $\sim 70 \mathrm{~km}$ wide by $\sim 350-\mathrm{km}$-long corridor in the Paleozoic fold-thrust belt above the ETSZ. Models of modern incision rates show a NE-SW trending swath of elevated erosion $\sim 30 \mathrm{~km}$ southeast of the center of the ETSZ. Stress modeling shows that lithologically focused erosion has affected fault clamping stress on preexisting, favorably oriented faults. We argue that the lithologically controlled transient erosional response to base level fall in the Upper Tennessee basin has given rise to and is sustaining earthquake activity in the ETSZ.

Plain Language Summary There is currently no adequate theory to explain earthquakes that occur far from plate boundaries, known as intraplate earthquakes, yet they represent a relevant seismic hazard to heavily populated regions like the central and eastern United States. Intraplate earthquakes are often observed in discrete zones defined by low levels of background seismicity and sometimes large, destructive,

historical earthquakes. Deriving new models and methodologies for understanding the mechanisms driving intraplate seismicity will improve regional earthquake hazard assessments. Here we present a new model for the eastern Tennessee seismic zone (ETSZ), the second most seismically active region in the central and eastern United States. We model the history of landscape evolution above the ETSZ and show that a zone of weak rocks allowed for focused erosion above the seismic zone. Using stress models, we demonstrate that this erosion was sufficient to unclamp preexisting faults, allowing them to reactivate in the regional stress field. This new model for the ETSZ and the methodology described can be applied to better understand intraplate earthquakes in the central and eastern United States as well as other intraplate settings globally.

\section{Introduction}

Plate tectonics theory explains the global distribution of most earthquakes, with seismicity concentrated along discrete plate boundaries. In contrast, the distribution and driving mechanisms of intraplate earthquakes, which occur in plate interiors far from plate boundaries, remain poorly understood (Stein, 2007). Seismicity in continental interiors is often observed in discrete zones, and progress has been made in demonstrating that many of these seismic zones exploit preexisting weaknesses (e.g., faults, fractures, and shear zones) in the mid-to-upper crust (e.g., Hughes et al., 2015; Powell \& Thomas, 2016). However, not all inherited structures in continental plate interiors are seismically active, and no universally accepted mechanism exists that explains the distribution and occurrence of intraplate earthquakes. This lack of a theoretical underpinning inhibits progress in understanding earthquake hazard potential in heavily populated intraplate settings, such as the central and eastern United States (Stein, 2007).

Various mechanisms have been proposed to explain specific instances of intraplate earthquakes and seismic zones throughout the globe. Far-field stresses, such as spreading ridge push, basal traction on the lithosphere due to mantle flow or some combination of both, can explain the regional state of stress in the crust but do little in helping predict the triggering mechanisms or spatial distribution of intraplate seismicity (Ghosh \& Holt, 2012; Richardson et al., 1979; Sykes \& Sbar, 1973). Locally weak lithosphere or regions underlain by adjacent lithospheric blocks of differing strength that might promote locally higher stress concentration are sometimes invoked to explain continental intraplate earthquakes (Powell et al., 1994; Zoback \& Richardson, 
1996). Transient perturbations to the regional stress field due to isostatic adjustments from glacial retreat, marine flooding of the continental shelf, or warping of the lithosphere due to dynamic topography or lithospheric foundering might also explain sites of elevated and depressed seismic activity away from plate boundaries (Biryol et al., 2016; Forte et al., 2007; Ghosh \& Holt, 2012; Stein et al., 1979). Some researchers have argued that intraplate seismic zones are the result of the gradual buildup of gravitational body forces due to lithospheric density contrasts (Levandowski et al., 2017). Others have suggested that intraplate seismicity might arise from stress changes induced by preferential surface erosion (Calais et al., 2010; Vernant et al., 2013).

Such a variety of models invoked to explain intraplate earthquakes suggests that their origins might be diverse. Nonetheless, three general characteristics emerge that are consistent among most models for intraplate seismicity: (1) the presence of inherited structures that are preferentially oriented in the ambient stress field, (2) crust that is critically stressed, and (3) fault slip that is facilitated by local perturbations in the regional stress field. The former two conditions are generally met in postorogenic (e.g., ancient convergent belts and postcollisional rift margins) intraplate settings. Postorogenic crust hosts numerous preexisting weaknesses of variable orientation and is subject to slow, long-term strain accumulation from processes such as ridge push and mantle-flow traction (Ghosh \& Holt, 2012; Richardson et al., 1979; Sykes \& Sbar, 1973). However, there is an ongoing debate regarding the specific processes driving local perturbations in the stress field that initiate intraplate seismicity in discrete zones.

The eastern Tennessee seismic zone (ETSZ) is the second most seismically active region in North America east of the Rocky Mountains (Figure 1). Here seismicity extends from northern Alabama to Kentucky, but most activity is concentrated in an $\sim 50$ by $300-\mathrm{km}$ corridor beneath the Valley and Ridge physiographic province, which is underlain by the Paleozoic (Alleghanian) fold-and-thrust belt (Figure 1; Powell et al., 1994). Despite historical seismicity of up to $M_{w} 4.8$, paleoseismic evidence of earthquakes $\geq M_{w} 6$ (Hatcher et al., 2013; Warrell et al., 2017) and its proximity to large populations centers such as Chattanooga and Knoxville, TN, the ETSZ has received far less attention than the New Madrid, Charleston, and Central Virginia Seismic Zones, which have all had historic, destructive earthquakes (Coffman et al., 1982).

Most studies of the ETSZ have focused on seismology, geophysics, and geology to identify the causative faults, kinematics, and geological context of seismicity (Chapman et al., 1997; Hatcher et al., 2013; Powell et al., 1994, 2014; Powell \& Thomas, 2016; Warrell et al., 2017). The few focal mechanisms reported for the ETSZ indicate strike-slip, transtensional, and normal motion, which is broadly consistent with microseismicity that illuminates steeply dipping, approximately NE-SW oriented structures in the subthrust belt basement (Chapman et al., 1997; Cooley, 2014; Levandowski et al., 2018; Powell et al., 1994). The strike of basement structures aligns with the direction of the regional maximum compressive stress (Mazzotti \& Townend, 2010), indicating that their orientation is favorable for reactivation with strike-slip kinematics.

Regarding the processes driving seismicity, the ETSZ is likely too far south to have experienced significant stress perturbations due to postglacial isostatic adjustments (Craig \& Calais, 2014). Alternately, it has been argued that intraplate stress concentrated along lithospheric blocks of different strengths on opposite sides of the seismic zone allows for slip on an ancient Grenvillian suture, defined by the New York-Alabama magnetic lineament (Powell et al., 1994; Powell \& Thomas, 2016). However, this model fails to explain why earthquakes only occur in the $\sim 300-\mathrm{km}$-long ETSZ and not along the entirety of the $\sim 1,600-\mathrm{km}$-long ancient basement lineament. Additionally, other studies have had difficulty resolving differences in mantle lithosphere structure across this boundary (Wagner et al., 2018). Lower crustal delamination and lithospheric foundering have been invoked to explain the ETSZ (Biryol et al., 2016; Graw et al., 2015), but such hypotheses are difficult to test with observational data from the geological record.

Here we present a new model for the ETSZ that suggests that lithological focusing of transient erosion in the Upper Tennessee drainage basin has augmented the local stress field through redistribution of surface loads, allowing preexisting basement structures to slip in the regional stress field. This research builds on a previous study that demonstrates that a transient wave of incision is sweeping through the Upper Tennessee drainage basin, which lies above the ETSZ (Gallen, 2018). The signal of base level fall is defined by a series of fluvial knickpoints that encircle the Valley and Ridge province (Figure 1). The observed knickpoint distribution implies that erosion has been preferentially focused downstream of the knickpoints in an $\sim 70 \mathrm{~km}$ wide by $\sim 350-\mathrm{km}$ corridor of relatively erodible rocks in the Valley and Ridge (Figure 1). In this study, we use 

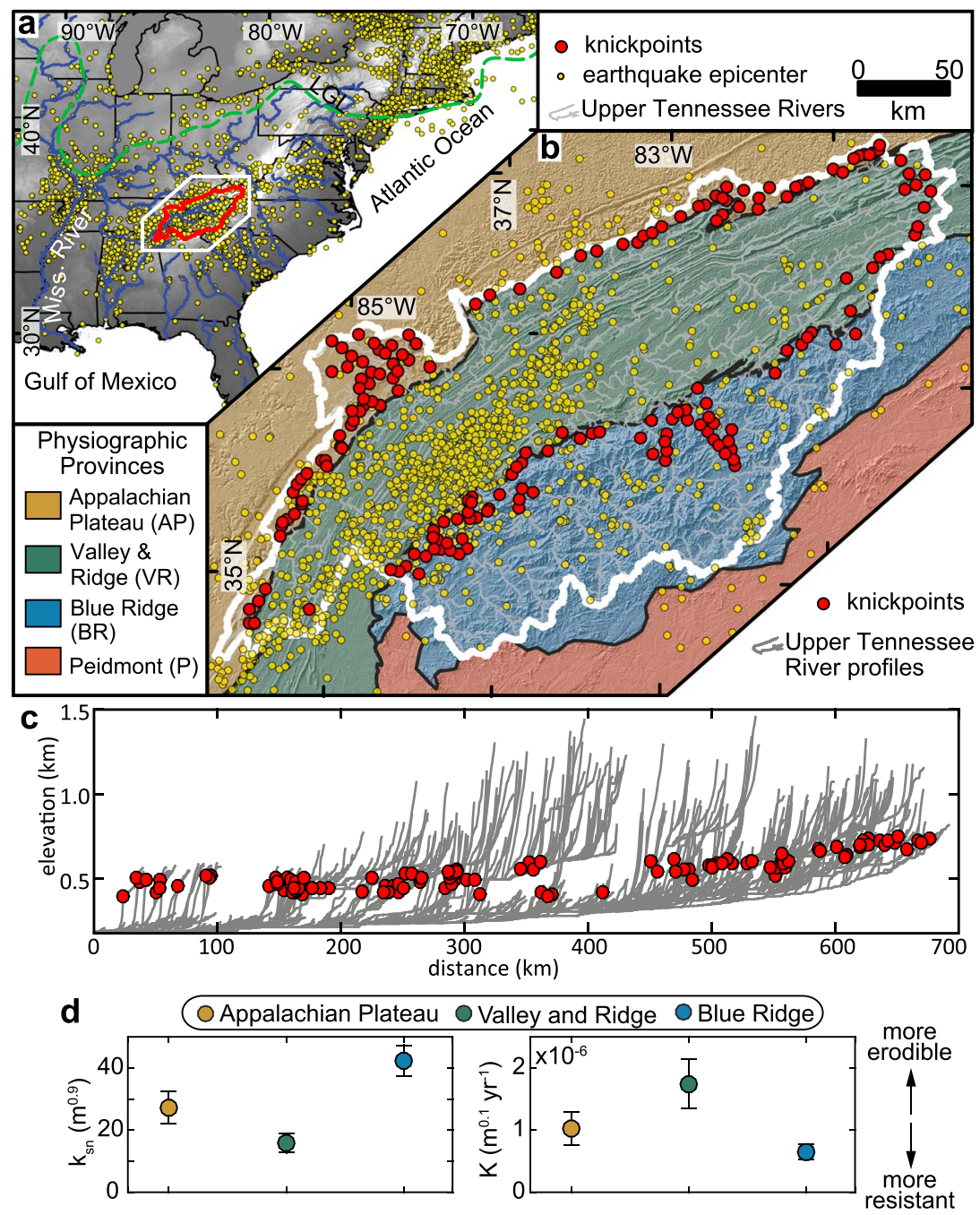

Figure 1. Regional setting, geology, and geomorphology of the Upper Tennessee River basin. (a) Shaded relief map of the eastern and central United States with major rivers shown in blue. Earthquake epicenters from the Virginia Tech Seismological Observatory (1901-2016), the location of Figure 1b (white outline), and the Upper Tennessee basin (red outline) are shown. (b) Hillshade of the Upper Tennessee basin with the physiographic provinces highlighted. The distribution of knickpoints (red dots) found between 400- and 600-m elevation represents the propagating front of landscape adjustment to a Late Miocene base level fall event at the basin outlet (from Gallen, 2018), and earthquake epicenters (yellow dots) from the Virginia Tech Seismological Observatory are shown. The eastern Tennessee seismic zone (ETSZ) is shown by the clustering of seismicity beneath the Valley and Ridge province. (c) Longitudinal river profiles for rivers draining $\geq 5 \mathrm{~km}^{2}$ in the Upper Tennessee basin with the location of the knickpoints (red dots). (d) Average normalized steepness index, $k_{s n}$, (left) and erodibility coefficient, $K$, (right) for each province in the Upper Tennessee basin (see section 3 for details on the calculations of $k_{s n}$ and $K$ ). These values are representative of the distribution of rock-type average $k_{s n}$ and $K$ calculated throughout the basin (Figure S1). Table S1 contains brief descriptions of the rock types in the Upper Tennessee drainage basin.

landscape reconstructions and analytical and numerical modeling to assess the impact of rock-type controlled preferential erosion on the origin and ongoing activity of the ETSZ.

\section{Background}

\subsection{Tectonic and Geological Setting}

The eastern margin of North America has experienced two complete Wilson cycles (Thomas, 2006) and three relatively discrete Paleozoic collisional events that culminated with the Alleghanian (Pennsylvanian-Permian) 
orogeny (Hatcher et al., 2007). Late Triassic rifting led to opening of the North Atlantic and development of a passive margin along eastern Laurentia (Hatcher, 1989). The tectonic and geologic history is strongly imprinted in the contemporary landscape, providing the basis for the classification of well-defined physiographic provinces (Figure 1). The passive margin drift history is recorded in Mesozoic-Cenozoic marine and terrestrial sediments that underlie the low-relief coastal plain. The crystalline cores of the Alleghanian and Neoacadian (Devonian) orogenies form the bedrock of the low-relief Piedmont province, and deeply exhumed mid-to-high metamorphic grade thrust sheets of the Taconic orogeny (Hatcher et al., 2007) comprise the high-relief Blue Ridge of the modern Appalachian Mountains. Deformed sedimentary rocks in the exhumed Alleghanian fold-thrust belt define the moderate relief Valley and Ridge province. Gently deformed subhorizontal rocks representing the same Valley and Ridge Paleozoic stratigraphy are located in the Appalachian Plateau.

\subsection{Geomorphology of the Upper Tennessee River Basin}

The Upper Tennessee River basin spans the Blue Ridge, Valley and Ridge, and Appalachian Plateau physiographic provinces, and variations in rock type are strongly expressed in the topography (Figures 1 and S1; Mills, 2003; Gallen, 2018). Relative to provinces to the west, the Blue Ridge consists of steep, high-relief terrain underlain by erosionally resistant metasedimentary rocks. In the Valley and Ridge, resistant sandstone and dolomite occupy ridgetops, while most of the province is defined by more erodible limestone and shale that underlie valleys. A resistant sandstone and conglomerate caprock overlies most of the Appalachian Plateau within the Upper Tennessee basin.

Gallen (2018) conducted a quantitative geomorphology study of the Upper Tennessee River system and identified a suite of fluvial knickpoints (sharp convex upward sections in a longitudinal river profile) that surround the Valley and Ridge province (Figure 1). This study showed that these knickpoints could be modeled as a kinematic wave sweeping through the basin due to a $150 \pm 25 \mathrm{~m}$ base level fall event that occurred at the mouth of the basin at $9 \pm 3 \mathrm{Ma}$ (Figure S2). The inferred amount of base level fall is consistent with the present-day elevation of the contact between the strong Appalachian Plateau capstone and underlying easily erodible shales, implying that eventual removal of the capstone is related to base level fall (Figure S2). On the basis of these results, coupled with existing geomorphological, sedimentological, and biological data sets, Gallen (2018) argued that base level fall was facilitated by capture of the Upper Tennessee basin by the Lower Tennessee basin. Gallen (2018) argued that capture was triggered by expansion of the Lower Tennessee basin in response to incision through the resistant Appalachian Plateau capstone. A detailed description of this study and the methodology used are in the supporting information (Goren et al., 2014; Tarantola, 1987). We use this study as a starting point to assess the geomorphic, isostatic, and crustal stress response to this landscape perturbation.

We first reconstruct the magnitude and spatial extent of differential erosion associated with Late Miocene base level fall and model the present-day distribution of river incision rates throughout the Upper Tennessee basin. We then assess the flexural isostatic response to differential erosional unloading. Finally, we use an analytical model to calculate unclamping stress on faults in the midcrust to evaluate the role of differential erosion on the origin and ongoing activity of the ETSZ.

\section{Methods}

\subsection{Geomorphic Analysis}

The pre-base level fall elevation of the Late Miocene paleo-Upper Tennessee river network is reconstructed assuming that local base level at the river outlet was $150 \pm 25 \mathrm{~m}$ higher than present based on the inverse modeling of Gallen (2018; Figure S2). We assume that the paleo-river network was in steady state and solve the equation:

$$
z(x)=z_{b}+\int_{x_{b}}^{x} k_{s n}\left(x^{\prime}\right) A\left(x^{\prime}\right)^{-m / n} d x^{\prime}
$$

where $x$ is distance, $z$ is elevation, $z_{b}$ is the paleo-base level elevation, $k_{s n}$ is the normalized channel steepness index, $A$ is drainage area, and $m$ and $n$ are positive constants, with a ratio equal to 0.45 (cf. Perron \& Royden, 2013). This ratio is consistent with that found as a local or regional average in the Appalachians (Gallen, 2018; Gallen et al., 2011, 2013; Miller et al., 2013). It is also in agreement with theoretical considerations that suggest 


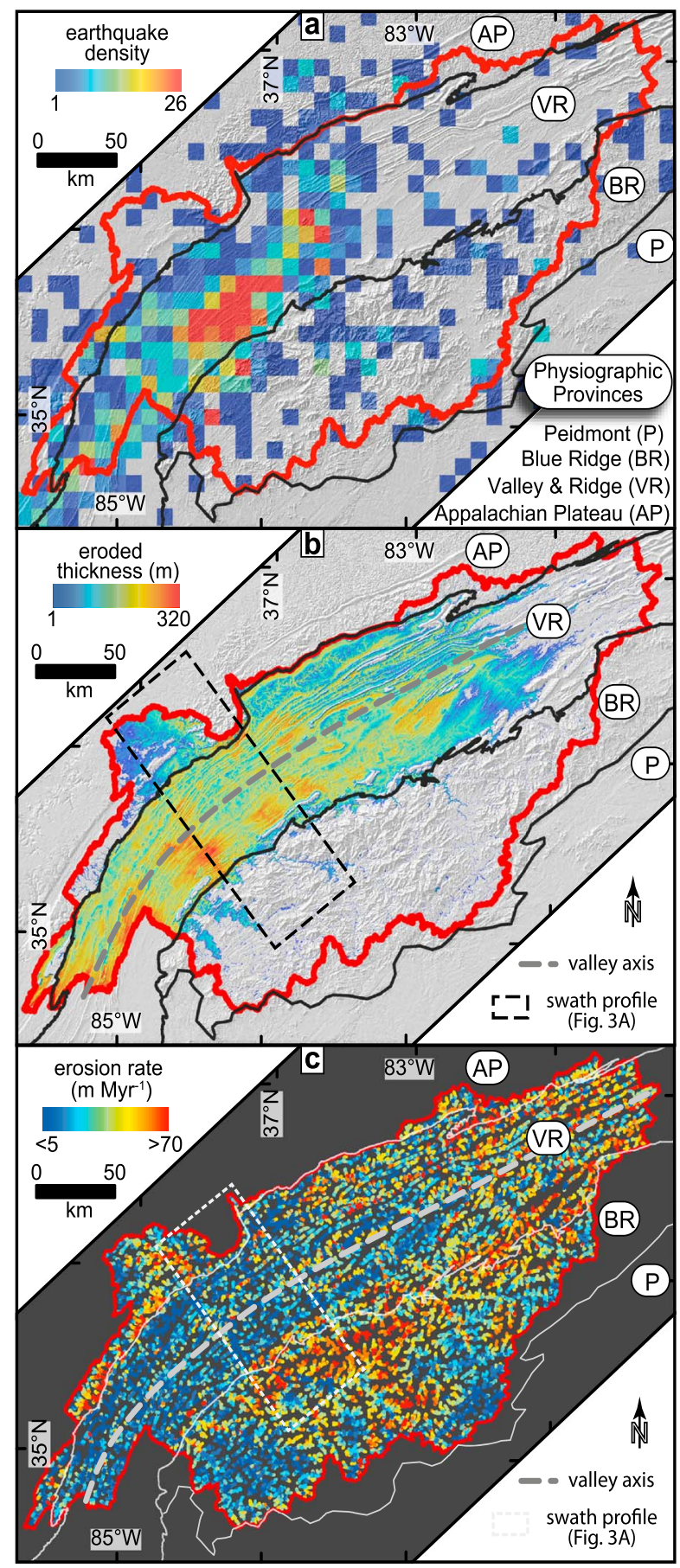

Figure 2. Earthquakes density and results from the geomorphic analysis. (a) Density map of earthquake epicenters per kilometer squared as determined from a $10 \mathrm{~km}$ moving window over the Virginia Tech Seismological Observatory catalog. (b) Map of mean eroded rock due to base level fall and upstream migration of knickpoints. The dashed gray line shows the central axis of the Upper Tennessee Valley, which is set as zero distance for the line load modeling and projection of the earthquake epicenters shown in Figure 4. The black dashed rectangle shows the location of the eroded thickness swath profile in Figure 4a. Note the correlation between eroded thickness in $b$ and the density of earthquakes generated in the ETSZ in a. (c) Map of modeled present-day erosion rate. The dashed white box shows the location of the swath shown in Figure 4c. Note the elevated zone of erosion along the western margin of the Blue Ridge province. that a well-adjusted river with spatially uniform uplift, lithology, and runoff should have an $m$ to $n$ ratio between 0.4 and 0.6 (Kirby \& Whipple, 2012). The normalized steepness index is a stream channel metric commonly used in tectonic geomorphology studies, and it is proportional to the ratio of river incision rate to bedrock erodibility raised to an exponent (Kirby \& Whipple, 2012; Whipple \& Tucker, 1999). The average $k_{s n}$ is calculated for eight geologic map units (Figure S1; see the supporting information for complete description of the methodology). For our paleo-elevation estimates, we use the path-dependent changes in rock-type-averaged $k_{s n}$ and drainage area defined by the modern river network to solve equation (1) and propagate uncertainties in the paleo-outlet elevation and $k_{s n}$ using a Monte Carlo routine. We use the paleo-elevation estimates along with the digital elevation model of the Upper Tennessee basin to quantify the spatial extent and volume of rock eroded downstream of the knickpoints by subtracting the two elevation models (Figures 2 and S3).

A model of the spatial distribution of modern erosion rates is generated by taking the derivative of river network elevation with respect to the response time of the river system, $\tau$. The river response time is calculated as (Whipple \& Tucker, 1999)

$$
\tau(x)=\int_{0}^{x} \frac{d x^{\prime}}{K\left(x^{\prime}\right) A\left(x^{\prime}\right)^{m}}
$$

where $K$ is a coefficient of erodibility that is calculated for the eight geologic map units by dividing the geologic unit average $k_{s n}$ by an assumed basin average erosion rate of $27 \pm 4 \mathrm{~m} / \mathrm{Ma}$. We use this basin-averaged erosion rate because it represents the regional average of the Appalachians integrated over a range of timescales from tens of thousands to hundreds of millions of years (Boettcher \& Milliken, 1994; Matmon, Bierman, Larsen, Southworth, Pavich, \& Caffee, 2003; Matmon, Bierman, Larsen, Southworth, Pavich, Finkel, et al., 2003).

\subsection{Flexural Isostasy}

We assess the flexural isostatic response to spatially focused erosional unloading in the Upper Tennessee basin and surrounding area. The area affected by the isostatic response is determined by the size of the load and the elastic strength of the lithosphere (Watts, 2001). We use an elastic plate model with an effective elastic thickness, $T_{e^{\prime}}$ a proxy for lithospheric elastic rigidity, ranging from 40 to $50 \mathrm{~km}$. These values encompass most of the range of $T_{e}$ in the study area as determined using a maximum entropy-based coherence method (Armstrong \& Watts, 2001). The isostatic response was calculated using a Young's modulus of $100 \mathrm{MPa}$, a Poisson's ratio of 0.25 , and densities of the eroded material and mantle of 2,700 and $3,300 \mathrm{~kg} / \mathrm{m}^{3}$, respectively. Calculations were made in the spectral domain, and forward and inverse fast Fourier transforms were used to move between the spatial and spectral domains.

\subsection{Stress Modeling}

To assess the role of spatially focused erosion on fault plane stress we used an analytical line load model that calculates 


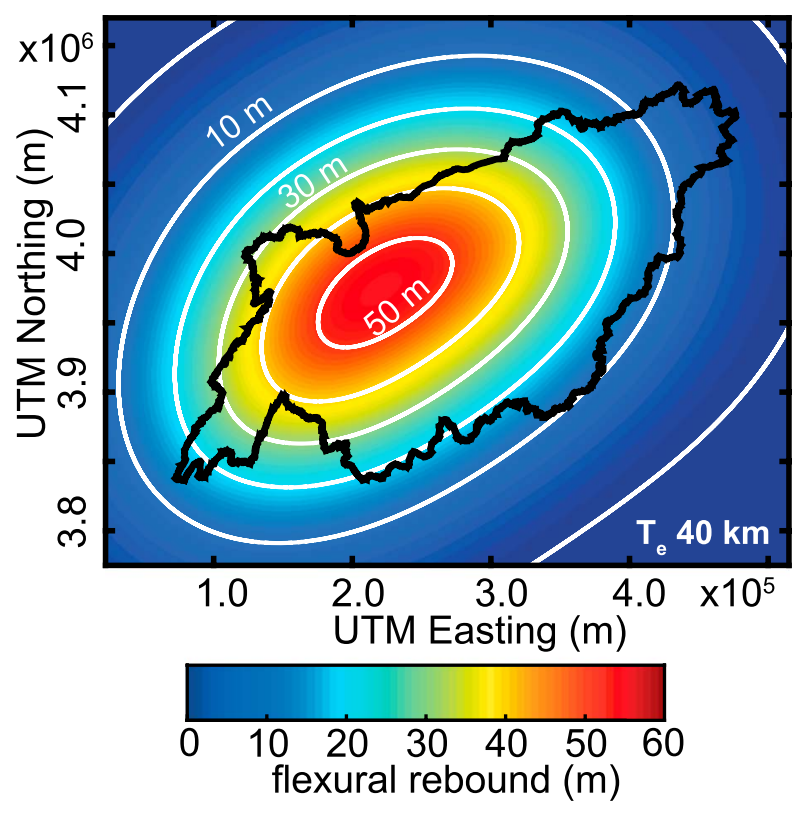

Figure 3. Modeled flexural isostatic response to erosion unloading of $\sim 3,500 \mathrm{~km}^{3}$ of rock in the Valley and Ridge province as shown in Figure $2 \mathrm{~b}$. This analysis assumes an effective elastic thickness $\left(T_{e}\right)$ of the lithosphere of $40 \mathrm{~km}$, which is consistent with the lower end of estimates derived for this region that range between 40 and $50 \mathrm{~km}$ (Armstrong \& Watts, 2001), to demonstrate the maximum anticipated flexural isostatic response to erosional unloading. two-dimensional (2-D) stress from surface loading or unloading of an elastic half-space at any point at depth (Jaeger et al., 2009; Amos et al., 2014; see the supporting information for full model details). The approximation of a 2-D line load is justified because the modeled loads are much longer than they are wide. We resolve the shear and normal stress on hypothetical fault planes of a range of dip angles, consistent with reactivated faults in the ETSZ that strike normal to the $x-z$ plane in our model (Figure S4). Assuming Coulomb failure, the change in Coulomb stress, $\Delta \sigma_{c}$, on the fault plane is calculated as

$$
\Delta \sigma_{c}=\Delta\left|\tau_{s}\right|+\mu \Delta \tau_{n}
$$

where $\Delta \tau_{s}$ is the change is shear stress, $\Delta \tau_{n}$ is the change in normal stress, and $\mu$ is the coefficient of friction, assumed to be 0.6. (Amos et al., 2014; Jaeger et al., 2009). This same equation can be used to calculate changes in stress rate when the time derivative of stress change is provided.

\section{Results}

The normalized steepness index of Valley and Ridge rock units is, on average, approximately a factor of 3 lower than adjacent units in the Blue Ridge and Appalachian Plateau provinces. This result implies that Valley and Ridge units are approximately 3 times more erodible than the flanking rock-types (Figures 1 and S1). These calculations are consistent with independent estimates of erodibility from the Valley and Ridge (Miller et al., 2013) and the Blue Ridge (Gallen et al., 2013) provinces as well as trends defined by basin average erosion rate and $k_{s n}$ data from similar rock-types throughout the Appalachians (Figure S1; Matmon, Bierman, Larsen, Southworth, Pavich, \& Caffee, 2003; Matmon, Bierman, Larsen, Southworth, Pavich, Finkel, et al., 2003; Marstellar, 2012; Miller et al., 2013; Duxbury et al., 2015; Linari et al., 2017).

Our paleo-topography reconstructions indicate that erosion was confined to an $\sim 70$ - by $350-\mathrm{km}$ corridor of highly erodible rocks in the Valley and Ridge (mostly carbonate and shale) (Figures 1, 2, and S3). The volume of rock preferentially removed from the Valley and Ridge due to differential erosion associated with the transient wave of erosion totals $\sim 3,551 \pm 783 \mathrm{~km}^{3}$, with an average eroded thickness of $\sim 150 \mathrm{~m}$ (Figures 2 and S3). Despite the large volume of preferentially eroded rock, the flexural isostatic response to focused erosion is only several tens of meters, due to the high rigidity of the lithosphere in this region (Armstrong \& Watts, 2001) (Figures 3 and S5). The map of modeled present-day river incision rates shows a zone of elevated erosion, more than double background, in an elongate NE-SW trending swath along the western margin of the Blue Ridge province (Figure 2c). The advancing knickpoint front defines the elevated zone of erosion and it is located $\sim 30 \mathrm{~km}$ southeast of the center of the ETSZ (Figures 1 and 2).

The highest density of ETSZ microseismicity is located at $\sim 15-\mathrm{km}$ depth beneath the zone of focused erosion (Figures 1, 2, and 4). Stress modeling indicates that maximum unclamping stresses on faults at 15-km depth are $>3 \mathrm{MPa}$, with maximum long-term time-averaged unclamping rates of nearly $0.4 \mathrm{~Pa} /$ year assuming that base level fall initiated at $9 \mathrm{Ma}$ (Figures $4 \mathrm{a}$ and 4b; Gallen, 2018). The location of the greatest reduction in modeled unclamping stress is spatially coincident with the highest density of historical seismicity (Figures 2 and 4). The swath of elevated present-day erosion rates along the western margin of the Blue Ridge is also predicted to perturb stress in the mid-to-upper crust and is capable of reducing clamping stress at a rate of $0.3-0.4 \mathrm{~Pa} /$ year in the ETSZ (Figures $4 \mathrm{c}$ and $4 \mathrm{~d}$ ).

\section{Discussion and Implications}

Relatively erodible shale and limestone in the Valley and Ridge allowed for rapid, focused removal of $\sim 3,500 \mathrm{~km}^{3}$ of rock in response to base level fall in the Late Miocene (Figures 2 and S3 and Movie S1). 

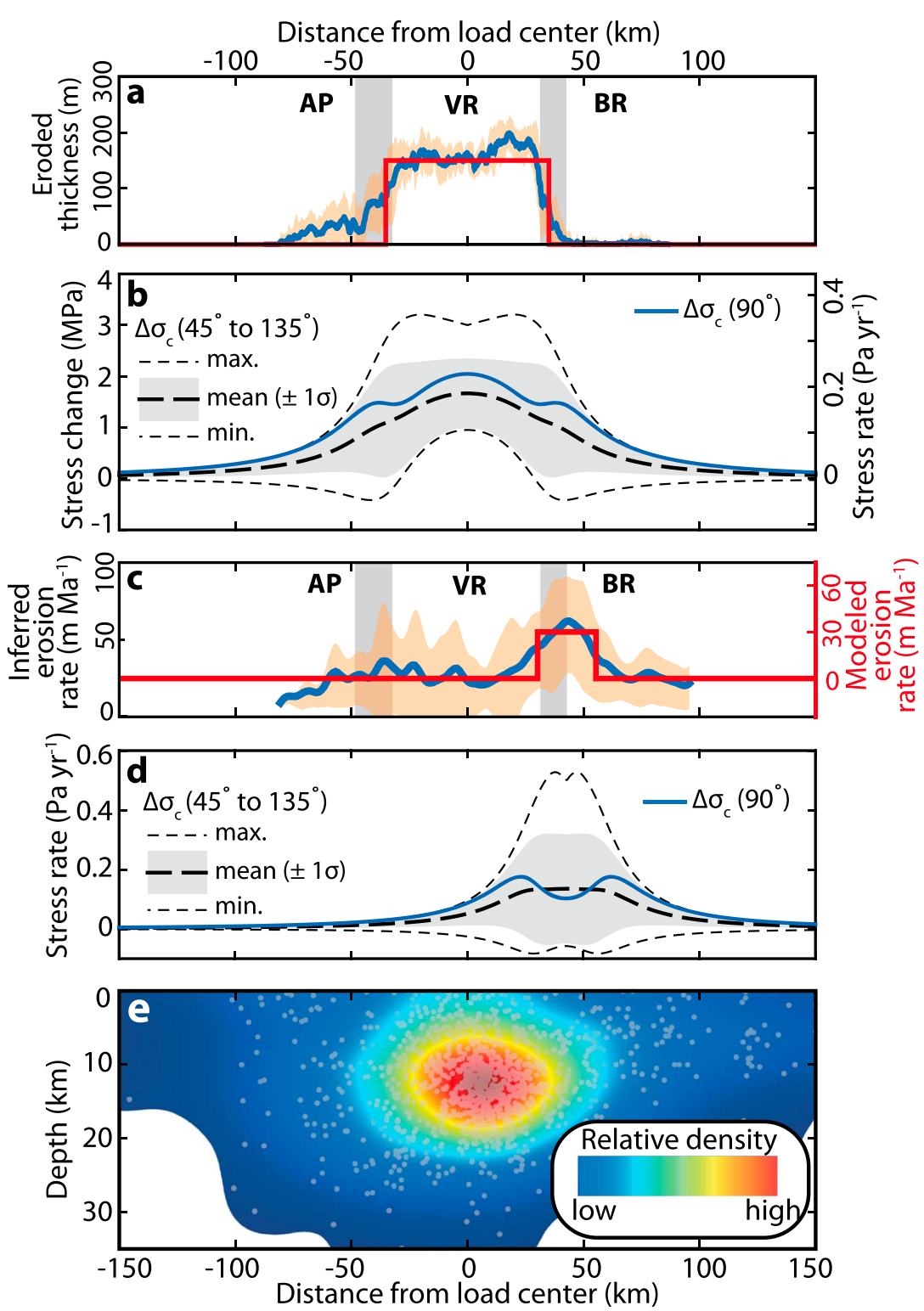

Figure 4. Stress modeling. (a) Swath profile of mean (blue line) $\pm 1 \sigma$ (shaded orange) eroded thickness derived from Figure 2a. The gray bars show the boundary between the Appalachian Plateau (AP), Valley and Ridge (VR), and Blue Ridge (BR) physiographic provinces within the swath. The average eroded thickness in the Valley and Ridge is $\sim 150 \mathrm{~m}$, and we use a simple step function, as shown by the red line, to simulate the changes in clamping stress on faults at $15 \mathrm{~km}$ depth. (b) Modeled changes in unclamping stress on hypothetical faults at $15-\mathrm{km}$ depth with dips ranging from $+45^{\circ}$ to $-45^{\circ}$ $\left(135^{\circ}\right)$ assumed to be striking normal to the $x z$ plane. The $y$ axis on the right-hand side of the plot shows the average rate of unclamping stress assuming a time-averaged erosion rate of $150 \mathrm{~m}$ of rock over a 9-Myr period, which is the favored timing of base level fall (Gallen, 2018). The plot shows the spread in data for faults of all dips considered. (c) Same as in a but showing modeled present-day erosion rates (d) Same as in b but the calculations are made using the erosion rate step function in c. (e) Location and kernel density plot of earthquake depths as projected onto the gray dashed line shown in Figures $2 \mathrm{~b}$ and $2 \mathrm{c}$.

The wave of enhanced incision slowed as it encountered more resistant sandstone and conglomerate in the Appalachian Plateau and metamorphic rock in the Blue Ridge, giving rise to the peculiar distribution of knickpoints surrounding the Valley and Ridge (Figures 1 and S2 and Movie S1). The differential response time of rivers incising variable lithology resulted in the development of a focused zone of erosion along the western edge of the Blue Ridge (Figures 1 and 2c). Despite the removal of such a large volume of rock, the amount of isostatically induced rock uplift is surprisingly small due to the high elastic rigidity of the 
lithosphere in this ancient orogenic belt (Figure 3). However, the preferential erosion of less resistant rocks substantially changed the clamping stress along preexisting basement structures (Figure 4).

The spatial coincidence between the location of the largest mass of rock preferentially eroded rock from the Valley and Ridge and earthquake density in the ETSZ hints at a causative link (Figures 2a and 2b). The correlation between the maximum unclamping stress and the highest concentration of seismicity supports this interpretation (Figures $4 \mathrm{~b}$ and $4 \mathrm{e}$ ). We argue that lithologically focused erosion allowed preferentially oriented preexisting basement structures to slip in the regional stress field and gave rise to the ETSZ. The pattern of modeled present-day incision rates suggests that base level fall and the lithologically controlled drainage basin response resulted in a pattern of differential erosion capable of affecting the local state of stress in the ETSZ today (Figures $2 \mathrm{c}$ and $4 \mathrm{c}$ and $4 \mathrm{~d}$ ). We suggest that modern differential erosion, perhaps coupled with changes in Coulomb stress and fault weakening due to ongoing earthquake activity, are sustaining the ETSZ. The slow response time of the Upper Tennessee River system (Gallen, 2018) resulted in a persistent zone of reduced clamping stress. While the rates of stress change are low, provided the crust is critically stressed, an infinitesimal amount of stress change would result in failure. Even if the crust is not critically stressed, when integrated over hundreds of thousands of years, these rates of stress change are large enough to promote fault unclamping and slip.

This new model for the ETSZ is consistent with the model of erosion-induced seismicity in the New Madrid Seismic Zone proposed by Calais et al. (2010) and suggests that intraplate earthquakes will occur on suitably oriented preexisting faults in a passing wake of transient erosion. Our model indicates that intraplate seismic zones triggered by focused erosion may not be stationary but can migrate through time. If faults favorably oriented in the regional stress field are located beneath these erosion hotspots, seismic zones will be located downstream of the erosional front and propagate headward following the migrating knickpoints. If correct, we expect that the ETSZ will become more diffuse and spread to the north and southeast through time. Within this framework, the propagation rate of the erosional front, and thus the migration rate of the ETSZ, is controlled by variations in erodibility and landscape response time associated with different rock-types.

Our proposed lithologically focused erosional unloading model for intraplate earthquakes is most applicable to postorogenic settings, as stark contrasts in rock strength are expected at the transition from crystalline to sedimentary units in ancient convergent orogens. Spatial variability in substrate erodibility will modify the erosional response and can act to focus erosion during periods of transient landscape evolution. A number of processes can trigger landscape transients, including incision through rocks of variable erodibility, river capture, climate change, or uplift from dynamic mantle processes. We expect intraplate seismicity to be repeatedly turned on and off as transient waves of incision intermittently sweep through the landscape and drive erosional focusing in swaths of less competent rock units. This model is also applicable to modern piggyback basins in fold-thrust belts, where the breaching of a basin will result in rapid erosion of the basin fill, changing the state of stress on underlying faults. We emphasize that this geomorphic model for intraplate seismicity does not exclude or invalidate other hypotheses regarding the ETSZ. Rather, several factors might contribute to the generation of earthquakes in the ETSZ and other intraplate seismic zones. Importantly, the model presented in this study makes several testable predictions, namely, a flexural isostatic response to erosional unloading and a distinct spatial pattern of present-day erosion rates.

\section{Conclusions}

We present observations that a transient wave of incision preferentially eroded $\sim 3,500 \mathrm{~km}^{3}$ of rock from relatively erodible lithologic units in the Alleghanian fold-thrust belt of the southern Appalachian Mountains. We show that there is a spatial correlation between this focused erosion and seismic activity on preexisting basement structures beneath the fold-thrust belt. Through stress modeling, we demonstrate that focused, differential erosion can drive a $>3-\mathrm{MPa}$ reduction in clamping stress along these structures and that modern differential erosion continues to affect crustal stress in the ETSZ. We use this evidence to suggest that lithologically focused erosion has given rise to and is sustaining the ETSZ by allowing optimally oriented structures to slip in the ambient, regional stress field. This model can be applied to other continental intraplate seismic zones, provided spatial variations in bedrock erodibility allow erosion to be spatially focused. Ancient convergent mountain belts are likely to meet these criteria best, and this model might help explain anomalous or elevated seismicity beneath erodible rock units in modern fold-thrust belts. 
Acknowledgments

The digital elevation model data and the digital geologic maps used in this study are available through the U.S. Geological Survey at earthexplorer.usgs. gov and ngmdb.usgs.gov, respectively. The authors declare no conflicts of interest. The authors would like to thank Oliver Boyd and an anonymous reviewer for comments that helped improve the clarity of this manuscript.

\section{References}

Amos, C. B., Audet, P., Hammond, W. C., Bürgmann, R., Johanson, I. A., \& Blewitt, G. (2014). Uplift and seismicity driven by groundwater depletion in central California. Nature, 509(7501), 483-486. https://doi.org/10.1038/nature13275

Armstrong, G. D., \& Watts, A. B. (2001). Spatial variations in Te in the southern Appalachians, eastern United States. Journal of Geophysical Research, 106(B10), 22009-22026. https://doi.org/10.1029/2001JB000284

Biryol, C. B., Wagner, L. S., Fischer, K. M., \& Hawman, R. B. (2016). Relationship between observed upper mantle structures and recent tectonic activity across the southeastern United States. Journal of Geophysical Research: Solid Earth, 121, 3393-3414. https://doi.org/10.1002/ 2015JB012698

Boettcher, S. S., \& Milliken, K. L. (1994). Mesozoic-Cenozoic unroofing of the southern Appalachian Basin: Apatite fission track evidence. Journal of Geology, 102(6), 655-668. https://doi.org/10.1086/629710

Calais, E., Freed, A. M., Van Arsdale, R., \& Stein, S. (2010). Triggering of New Madrid seismicity by late-Pleistocene erosion. Nature, 466(7306), 608-611. https://doi.org/10.1038/nature09258

Chapman, M. C., Powell, C. A., Vlahovic, G., \& Sibol, M. S. (1997). A statistical analysis of earthquake focal mechanisms and epicenter locations in the eastern Tennessee seismic zone. Bulletin of the Seismological Society of America, 87(6), 1522-1536.

Coffman, J. L., Von Hake, C. A., \& Stover, C. W. (1982). Earthquake history of the United States, Report Rep. 41-1, (revised edition with sup plement), U.S. Dept. of Commerce, NOAA, and the U.S. Geological Survey joint publication (p. 277). Boulder, CO.

Cooley, M. T. (2014). A new set of focal mechanisms and a geodynamic model for the eastern Tennessee seismic zone, (Master's thesis). Retrieved from the University of Memphis Electronic Thesis and Dissertations Repository (https://umwa.memphis.edu/etd/) Memphis, TN: The University of Memphis.

Craig, T. J., \& Calais, E. (2014). Strain accumulation in the New Madrid and Wabash Valley seismic zones from 14 years of continuous GPS observation. Journal of Geophysical Research: Solid Earth, 119, 9110-9129. https://doi.org/10.1002/2014JB011498

Duxbury, J., Bierman, P. R., Portenga, E. W., Pavich, M. J., Southworth, S., \& Freeman, S. P. H. T. (2015). Erosion rates in and around Shenandoah National Park, Virginia, determined using analysis of cosmogenic 10Be. American Journal of Science, 315(1), 46-76. https://doi.org/10.2475/ 01.2015 .02

Forte, A. M., Mitrovica, J. X., Moucha, R., Simmons, N. A., \& Grand, S. P. (2007). Descent of the ancient Farallon slab drives localized mantle flow below the New Madrid seismic zone. Geophysical Research Letters, 34, L04308. https://doi.org/10.1029/2006GL027895

Gallen, S. F. (2018). Lithologic controls on landscape dynamics and aquatic species evolution in post-orogenic mountains. Earth and Planetary Science Letters, 493, 150-160. https://doi.org/10.1016/j.epsl.2018.04.029

Gallen, S. F., Wegmann, K. W., \& Bohnenstiehl, D. R. (2013). Miocene rejuvenation of topographic relief in the southern Appalachians. GSA Today, 23(2), 4-10. https://doi.org/10.1130/GSATG163A.1

Gallen, S. F., Wegmann, K. W., Frankel, K. L., Hughes, S., Lewis, R. Q., Lyons, N., et al. (2011). Hillslope response to knickpoint migration in the southern Appalachians: Implications for the evolution of post-orogenic landscapes. Earth Surface Processes and Landforms, 36(9), 1254-1267. https://doi.org/10.1002/esp.2150

Ghosh, A., \& Holt, W. E. (2012). Plate motions and stresses from global dynamic models. Science, 335(6070), 838-843. https://doi.org/10.1126/ science.1214209

Goren, L., Fox, M., \& Willett, S. D. (2014). Tectonics from fluvial topography using formal linear inversion: Theory and applications to the Inyo Mountains, California. Journal of Geophysical Research: Earth Surface, 119, 1651-1681. https://doi.org/10.1002/2014JF003079

Graw, J. H., Powell, C. A., \& Langston, C. A. (2015). Crustal and upper mantle velocity structure in the vicinity of the eastern Tennessee seismic zone based upon radial P wave transfer functions. Journal of Geophysical Research: Solid Earth, 120, 243-258. https://doi.org/10.1002/ $2014 J B 011516$

Hatcher, J. R. D., Bream, B. R., \& Merschat, A. J. (2007). Tectonic map of the southern and central Appalachians: A tale of three orogens and a complete Wilson cycle. In J. R. D. Hatcher, M. P. Carlson, J. H. McBride, \& J. R. M. Catalán (Eds.), 4-D Framework of Continental Crust. Geological Society of America Memoir, 200 595-632. https://doi.org/10.1130/2007.1200(29)

Hatcher, J. R. D., Vaughn, J. D., \& Obermeier, S. F. (2013). Large earthquake paleoseismology in the East Tennessee seismic zone: Results of an 18-month pilot study. In R. T. Cox, M. P. Tuttle, O. S. Boyd, \& J. Locat (Eds.), Recent advances in North American paleoseismology and Neotectonics east of the Rockies. Geological Society of America, Special Paper, 493, 111-142. https://doi.org/10.1130/2012.2493(06)

Hatcher, R. D. J. (1989). Tectonic synthesis of the U.S. Appalachians. In R. D. J. Hatcher, W. A. Thomas, \& G. W. Viele (Eds.), The Appalachian-Ouachita Orogen in the United States (pp. 511-531). Boulder, CO.: The Geological Society of America. https://doi.org/ 10.1130/DNAG-GNA-F2.511

Hughes, K. S., Hibbard, J. P., \& Bohnenstiehl, D. R. (2015). In J. J. W. Horton, M. C. Chapman, \& R. A. Green (Eds.), Relict Paleozoic faults in the epicentral area of the 23 August 2011 central Virginia earthquake: Assessing the relationship between preexisting strain and modern seismicity. Geological Society of America, Special Paper, 509, 331-343.

Jaeger, J. C., Cook, N. G., \& Zimmerman, R. (2009). Fundamentals of rock mechanics (p. 488). Malden, MA: John Wiley.

Kirby, E., \& Whipple, K. X. (2012). Expression of active tectonics in erosional landscapes. Journal of Structural Geology, 44(0), 54-75. https://doi. org/10.1016/j.jsg.2012.07.009

Levandowski, W., Herrmann, R. B., Briggs, R., Boyd, O., \& Gold, R. (2018). An updated stress map of the continental United States reveals heterogeneous intraplate stress. Nature Geoscience, 11(6), 433-437. https://doi.org/10.1038/s41561-018-0120-x

Levandowski, W., Zellman, M., \& Briggs, R. (2017). Gravitational body forces focus North American intraplate earthquakes. Nature Communications, 8, 14314. https://doi.org/10.1038/ncomms14314

Linari, C. L., Bierman, P. R., Portenga, E. W., Pavich, M. J., Finkel, R. C., \& Freeman, S. P. H. T. (2017). Rates of erosion and landscape change along the Blue Ridge escarpment, southern Appalachian Mountains, estimated from in situ cosmogenic 10Be. Earth Surface Processes and Landforms, 42(6), 928-940. https://doi.org/10.1002/esp.4051

Marstellar, T. L. (2012). Investigating sediment source to sink processes in a post-orogenic landscape, (Master's thesis). Retrieved from SMARTech. (https://smartech.gatech.edu/handle/1853/47549) Atlanta, GA: Georgia Institute of Technology.

Matmon, A., Bierman, P. R., Larsen, J., Southworth, S., Pavich, M., \& Caffee, M. (2003). Temporally and spatially uniform rates of erosion in the southern Appalachian Great Smoky Mountains. Geology, 31(2), 155-158. https://doi.org/10.1130/0091-7613(2003)031<0155: tasuro $>2.0 . c 0 ; 2$

Matmon, A., Bierman, P. R., Larsen, J., Southworth, S., Pavich, M., Finkel, R., et al. (2003). Erosion of an Ancient Mountain Range, The Great Smoky Mountains, North Carolina and Tennessee. American Journal of Science, 303(9), 817-855. https://doi.org/10.2475/ajs.303.9.817

Mazzotti, S. p., \& Townend, J. (2010). State of stress in central and eastern North American seismic zones. Lithosphere, 2(2), 76-83. https://doi. org/10.1130/L65.1 
Miller, S. R., Sak, P. B., Kirby, E., \& Bierman, P. R. (2013). Neogene rejuvenation of central Appalachian topography: Evidence for differential rock uplift from stream profiles and erosion rates. Earth and Planetary Science Letters, 369-370(0), 1-12. https://doi.org/10.1016/j.epsl.2013.04.007

Mills, H. H. (2003). Inferring erosional resistance of bedrock units in the east Tennessee mountains from digital elevation data. Geomorphology, 55(1-4), 263-281. https://doi.org/10.1016/S0169-555X(03)00144-2

Perron, J. T., \& Royden, L. (2013). An integral approach to bedrock river profile analysis. Earth Surface Processes and Landforms, 38(6), 570-576. https://doi.org/10.1002/esp.3302

Powell, C. A., Bollinger, G. A., Chapman, M. C., Sibol, M. S., Johnston, A. C., \& Wheeler, R. L. (1994). A Seismotectonic model for the 300kilometer-long eastern Tennessee seismic zone. Science, 264(5159), 686-688. https://doi.org/10.1126/science.264.5159.686

Powell, C. A., \& Thomas, W. A. (2016). Grenville basement structure associated with the eastern Tennessee seismic zone, southeastern USA Geology, 44(1), 39-42. https://doi.org/10.1130/G37269.1

Powell, C. A., Withers, M. M., Cox, R. T., Vlahovic, G., \& Arroucau, P. (2014). Crustal velocity structure associated with the eastern Tennessee seismic zone: Vp and vs images based upon local earthquake tomography. Journal of Geophysical Research: Solid Earth, 119, $464-489$. https://doi.org/10.1002/2013JB010433

Richardson, R. M., Solomon, S. C., \& Sleep, N. H. (1979). Tectonic stress in the plates. Reviews of Geophysics, 17(5), 981-1019. https://doi.org/ 10.1029/RG017i005p00981

Stein, S. (2007). Approaches to continental intraplate earthquake issues. In S. Stein \& S. Mazzotti (Eds.). Geological Society of America, Special Paper, 425, 1-16.

Stein, S., Sleep, N. H., Geller, R. J., Wang, S.-C., \& Kroeger, G. C. (1979). Earthquakes along the passive margin of eastern Canada. Geophysical Research Letters, 6(7), 537-540. https://doi.org/10.1029/GL006i007p00537

Sykes, L. R., \& Sbar, M. L. (1973). Intraplate earthquakes, lithospheric stresses and the driving mechanism of plate tectonics. Nature, 245(5424), 298-302. https://doi.org/10.1038/245298a0

Tarantola, A. (1987). Inverse Problem Theory: Methods for Data Fitting and Parameter Estimation. Amsterdam: Elsevier.

Thomas, W. A. (2006). Tectonic inheritance at a continental margin, GSA Today, 16(2), 4-11. https://doi.org/10.1130/1052-5173(2006)016<4: TIAACM $>2.0 . C O ; 2$

Vernant, P., Hivert, F., Chéry, J., Steer, P., Cattin, R., \& Rigo, A. (2013). Erosion-induced isostatic rebound triggers extension in low convergent mountain ranges. Geology, 41(4), 467-470. https://doi.org/10.1130/G33942.1

Wagner, L. S., Fischer, K. M., Hawman, R., Hopper, E., \& Howell, D. (2018). The relative roles of inheritance and long-term passive margin lithospheric evolution on the modern structure and tectonic activity in the southeastern United States. Geosphere, 14(4), 1385-1410. https://doi.org/10.1130/GES01593.1

Warrell, K. F., Cox, R. T., Hatcher, R. D., Vaughn, J. D., \& Counts, R. (2017). Paleoseismic evidence for multiple Mw $\geq 6$ earthquakes in the eastern Tennessee seismic zone during the Late Quaternary. Bulletin of the Seismological Society of America, 107(4), 1610-1624. https://doi.org/ $10.1785 / 0120160161$

Watts, A. B. (2001). Isostasy and flexure of the lithosphere. Cambridge, UK: Cambridge University Press.

Whipple, K. X., \& Tucker, G. E. (1999). Dynamics of the stream-power river incision model: Implications for height limits of mountain ranges, landscape response timescales, and research needs. Journal of Geophysical Research, 104(B8), 17661-17674. https://doi.org/10.1029/ 1999JB900120

Zoback, M. L., \& Richardson, R. M. (1996). Stress perturbation associated with the Amazonas and other ancient continental rifts. Journal of Geophysical Research, 101(B3), 5459-5475. https://doi.org/10.1029/95JB03256 